\title{
Sir Richard Burton as Totemic Pantomime Demon in Postcolonial Theory
}

\author{
John Wallen \\ University of Sharjah, Unite Arab Emirates \\ E-mail: johnwallen79@gmail.com
}

\begin{abstract}
Received: 24-12-2016
Accepted: 28-03-2017

Advance Access Published: April 2017

Published: 01-07-2017

doi:10.7575/aiac.ijalel.v.6n.4p.255

URL: http://dx.doi.org/10.7575/aiac.ijalel.v.6n.4p.255
\end{abstract}

\begin{abstract}
The present article examines the ways in which the travels and journeys in Arabia and other Muslim lands of Richard Francis Burton, the nineteenth-century explorer and writer have, since the influential work of EdwardW. Said on Orientalism, been somewhat undervalued by contemporaries. It aims to offer a re-evaluation of those works and their contribution to Victorian knowledge. It will also offer a challenge to Said's account of Burton and, particularly in the second part, look at ways in which Burton has been viewed more generally by post-colonial theorists since Said's influential work.
\end{abstract}

Keywords: Richard Burton, Edward Said, Postcolonialism, Orientalism, Victorian explorers, Victorian science

\section{Introduction}

The present article examines the ways in which the travels and journeys in Arabia and other Muslim lands of Richard Francis Burton, the nineteenth-century explorer and writer have, since the influential work of Edward W. Said on Orientalism, been somewhat undervalued by contemporaries. It aims to offer a re-evaluation of those works and their contribution to Victorian knowledge. It will also offer a challenge to Said's account of Burton and, particularly in the second part, look at ways in which Burton has been viewed more generally by post-colonial theorists since Said's influential work.

A further aim I have is to bring together the viewpoints on Burton of the biographers and postcolonial critics who appear to have previously worked largely in isolation from one another. It is my belief that such a union will lead to a mutually beneficial process of cross-fertilization that will reveal a more complicated — and also more accurate-Burton for detailed future consideration and discussion. Finally, it is my hope that the effect of allowing Burton to emerge in all his nuanced complexity will make it very clear that he is far too multi-faceted a figure to be placed permanently within the restrictive confines of Said's discourse on Orientalism. Therefore, my objective is to dissociate Burton from the Orientalist and postcolonial discourse and suggest that he can be better and more sympathetically viewed through the perspective of other discourses about the Victorian world such as those connected with travel writing, important nineteenth-century figures who were sympathetic to Islam, and the development of the scientific method.

\section{Part I}

Burton is still perhaps best remembered as the adventurer who penetrated Makkah disguised as a Muslim pilgrim, but his contribution to the infant scientific disciplines of his time such as ethnography, archaeology and comparative religion are generally under- appreciated and statements of praise about his achievements, muted. This is partly due to his own irascible temperament and tendency, in at least some of his works, to promote a kind of scientific racism (and even to flirt with such a pseudo-science as phrenology: the elucidation of character by the examination of skull shape). However, I would contend that the chief reason Burton is hardly given his due today is as a consequence of Edward Said's branding of him as an "Orientalist": that blanket word of condemnation that can mean so little or so much. As I will argue in the later part of the present essay, this underestimation has continued in the work of latter-day postcolonial theorists right up until the present.

In his Preface to the twenty-fifth anniversary edition of Orientalism, Said says the following about his views of Orientalist methods as opposed to genuine research:

What I do argue also is that there is a difference between knowledge of other peoples and other times that is the result of understanding, compassion, careful study and analysis for their own sakes, and on the other hand knowledge - if that is what it is - that is part of an overall campaign of self-affirmation, belligerency, and outright war. 
According to Said, "Orientalism" is a kind of pseudo-academic discipline created for the purpose of subjugating the East to European - and latterly_-American power. Said, in his Introduction (written in 2003), argues convincingly that the reasons for the Iraqi war were based on the need to secure the flow of oil rather than on any disinterested concern for liberty and democracy in the region.

Even with all its terrible failings and its appalling dictator (who was partly created by U.S. policy two decades ago), were Iraq to have been the world's largest exporter of bananas or oranges, surely there would have been no war....

In other words, Orientalism - an activity that commences seriously from the time of Napoleon's entry into Egypt in 1798- has taken on new forms and expressions in the modern world, but largely remains the same aggressive imperialist activity that began more than 200 years ago.

Twenty-five years after its publication, Orientalism once again raises the question of whether modern imperialism ever ended, or whether it has continued in the Orient since Napoleon's entry into Egypt two centuries ago.

More recent work in the field of travel literature as genre and ideology--one of the areas that has been the focus of increased scholarly and critical attention since the first publication of Orientalism--can be said to be sympathetic to Said's essential arguments. For example, Mary Louise Pratt in her important book, Imperial Eyes: Travel Writing and Transculturation, emphasizes how encounters in what she calls "the contact zone" between imperialists and colonial peoples have taken place on an unequal footing between exploiters and the exploited. The book's "predominant theme" is: "how travel books by Europeans about non-European parts of the world went (and go) about creating the domestic subject of Euro-imperialism; how they have engaged metropolitan reading publics with (or to) expansionist enterprises whose material benefits accrued mainly to the very few."

As is the case with Said's Orientalism, there is much to be said for this argument (colonialism was clearly never conducted for the benefit of the colonized). However, also like Said, Pratt's argument sometimes suffers from its polemical exclusivity. A critic might make the point that such writings have reduced travel to imperialism and travel writing to imperialist propaganda. It might be further pointed out that this view of travel writing has rather lost sight of the global context of travel and travel writing, which has by no means been an exclusively European activity. Ibn Battuta, for example, the fourteenth-century Moroccan traveler, visited India, China and Tanzania. Furthermore, he left a record of his extensive travels in the Rihla, or "Journey" which he dictated to a scholar whom he had met in Grenada called Ibn Juzayy. Although possibly fictional in parts, the Rihla still gives a compelling and unique account of the fourteenth-century world.

In her book Ulysses' Sail: An Ethnographic Odyssey of Power, Knowledge, and Geographical Distance, anthropologist Mary W. Helms, while recognizing the frequently important connection between travel writing and imperialism, situates travel writing in a wider global and thematic perspective. ${ }^{\mathrm{vi}}$ According to Helms, travel to foreign lands is undertaken for a multiplicity of reasons (including political, social, economic, and cultural) and these interests can be said to fuel the human desire to travel in search of communication and exchange. However, travel does not reduce simply to imperialism, nor travel accounts to imperialist propaganda. On this view, it might be said that Pratt-- and Said, too--have offered an insightful but Eurocentric view of European travelers.

Robert J. C. Young in his first book, White Mythologies ${ }^{\text {vii }}$ also emphasizes the ways in which Europe has replicated itself in the rest of the world. History, contends Young (and particularly Marxist history), has always seen Europe as being at the center of things with the rest of the world portrayed as dormant and quiescent. However, Young is also critical of Said's emphasis on the importance of the intellectual in changing the world and his mistake (according to Young) in seeing the battle of oppositional ideas within traditional concepts of "high culture". viii

Ever since the time of its first publication in 1978, Said's concept of Orientalism as a pseudo-academic discipline has had severe critics. For example, Bernard Lewis comes in for scathing criticism in Orientalism as a prime- example of the kind of self-serving academic with a hidden imperialist agenda who has corrupted all reasonable academic treatment of Oriental themes. ${ }^{\text {ix }}$ Lewis makes some interesting would-be rebuttals to Said--that are often not without merit--in his 1982 article, "The Question of Orientalism," which appeared in the New York Review of Books. Perhaps most importantly he emphasizes how, historically speaking, Orientalism is merely a descriptive term for an area of intellectual research, being no more than a branch of historical and ethnographical knowledge (not unlike "Hellenism" or "Hebraism").

What then is Orientalism? In the past, Orientalism was used mainly in two senses. One is a school of painting -that of a group of artists, mostly from Western Europe, who visited the Middle East and North Africa and depicted what they saw or imagined sometimes in a rather romantic and extravagant manner. The second and more common meaning, unconnected with the first, has been a branch of scholarship. 
Lewis here argues that Orientalism was originally no more than a useful term for the description and analysis of Eastern languages and culture--though it is perhaps a little disturbing that he sees no connection between Orientalism as a style of painting and as a specific type of scholarship. No doubt his opponents would discern a clear relationship between the earlier florid and exaggerated painting style and the later academic discipline. After all, both might be considered Eurocentric, a way of seeing the East through Western eyes in an essentially unreal way. Nevertheless, Lewis goes on to accurately point out that Orientalists at this time were essentially philologists.

Basically these early scholars were philologists concerned with the recovery, study, publication, and interpretation of texts... The term Orientalist was not at that time as vague and imprecise as it appears now. ${ }^{\mathrm{x}}$

Lewis contends that Said ignores the long and very real contribution that the Orientalists have made to knowledge, such as the decipherment of the Egyptian hieroglyphics in the aftermath of Napoleon's invasion of Egypt in 1798 . $^{\text {xii }}$ He also points out that interest in the Middle East had existed in Europe since at least Renaissance times - a period long before the onset of European colonialism. ${ }^{\text {xiii }}$

Orientalism then, according to Lewis, is a critical discipline with a long history of honest research:

The most important question -- least mentioned by the current wave of critics -- is that of the scholarly merits, indeed the scholarly validity, of Orientalist findings. Prudently, Mr. Said has hardly touched on this question, and has indeed given very little attention to the scholarly writings of the scholars whose putative attitudes, motives, and purposes form the theme of his book.

Martin Kramer (who had his PhD thesis supervised by Lewis) is another scholar who is skeptical of Said's achievements. Much of his book, Ivory Towers on Sand, ${ }^{\mathrm{xv}}$ is an attack on Said's Orientalism. He begins by stating that Said himself came from a well-to-do background ${ }^{\mathrm{xvi}}$ and was considered simply as a member of the academic elite until the late nineteen-seventies and his opportune discovery of a new radical identity--just at a time when journalists were desperately seeking out articulate views on the Palestinian question. Thus, his suggestion is that Said was something of an ambitious charlatan even from the beginning:

In the years that followed, Said evolved into a public intellectual, meeting the growing American demand for a Palestinian perspective...Said was combative in argumentation and concise in formulation, and he entered their Rolodexes immediately.

According to Kramer, Said took only those examples from history and literature that were in tune with his own view point, in the process ignoring far more relevant examples that would have contributed towards disproving his theories (particularly the importance of Germany - a country without 'oriental' colonies - in developing European knowledge about 'the Orient'). Kramer states that over the last twenty years Said's views have been discredited by scholars from many different disciplines. However, they have all agreed on the one essential point: that Said selectively chose his examples in order to suit his case. The inclusion of contrary arguments would have toppled Said's thesis, since it demonstrated that the Western understanding and representation of the East-especially the Arabs and Islam-had grown ever more ambivalent, nuanced, and diverse.

Kramer also argues that Said's Orientalism appeared at a particularly sensitive time in American history, when lots of academics from abroad were seeking university positions. Orientalism, and the later development of post-colonial criticism, gave them a significant boost in their search. Suddenly, they were the experts, like Said himself, on the new inter- disciplinary theory of post-colonialism. ${ }^{\text {xix }}$ Furthermore, according to Kramer, there was the mostly unexpressed belief that only the exploited could accurately depict the actual process of exploitation--even given the fact that most of these new intellectuals, like Said himself, had come from well-to-do backgrounds. Kramer also assigns Said's influence to the coincidence of Orientalism with a particular moment in the history of the left in the academy:

Orientalism also arrived at a crucial moment in the evolution of third worldism in American academe. By 1978, the enthusiasm for third world revolutions had ebbed among American intellectuals...But an entire generation of leftist scholars nurtured on radical commitments had already made their way through doctoral programs, and desperately needed a manifesto to carry them over the next hurdle. ${ }^{\mathrm{xx}}$

Kramer is often more concerned with the politics of the academy than with Said's analysis of Orientalism. On the other hand, if he is correct in his analysis, a significant link emerges between the success of Said's book and the academic politics of the time.

In 2006, historian and novelist Robert Irwin published his critique of Said's thesis, Dangerous Knowledge: Orientalism and its Discontents. ${ }^{\text {xxi }}$ Asked about the necessity for such a book, Irwin repeated Lewis's earlier argument about the 
need to protect the intellectual heritage of the Orientalists themselves. However, he also makes one comment of a personal kind that does, one feels, instinctively act as a genuine criticism of Said and his supporters.

I also got irritated with people who thought that my researches in the Mamluk Sultanate in late medieval Egypt and Syria necessarily had some sort of sinister agenda. Even my wife seemed to favor this notion.

As a historian, Irwin criticizes Said harshly for ignoring German Orientalism and Russian designs on the southern Caucasus region. Furthermore, he berates Said for a general lack of historical knowledge concerning the roots of Orientalism:

To point out the obvious, Said was not a historian. He had no idea then how very few universities there were in 17th, 18th and 19th centuries Europe - and most of these were in Germany...If there were as many as half a dozen academic Arabists in Britain in the early 19th century I would be astonished. ${ }^{\text {xiii }}$

Of course, the more severe critics of Said's work have long since been in a vocal minority. The central tenets of Orientalism have, by this time, been mostly accepted--and often with enthusiasm--in the majority of Western universities. However, this does not mean that Said's ideas have received universal praise, even by his advocates. Many scholars, such as Maya Jassanoff, are able to see the discrepancies in Said's text (the bias, the ignoring of Germany and Russia, the careful arrangement of detail with the object of reaching a pre-ordained conclusion), but are yet able to praise him for his far-seeing intellectual vision.

In a review of Irwin's book, For Lust of Knowing: the Orientalists and their Enemies, she criticizes Irwin's piece-meal objections to Said's work and insists that, to be taken seriously, such criticism needs to confront Said on the ideological battlefield itself:

Given that Said's work hinges on the argument that imperial power drives Orientalism (and vice versa), a book challenging him ought to address these issues head on.

When Maya Jassanoff refers to Irwin needing to confront Said on the "ideological battlefield", she is no doubt referring to the structuring of Said's argument in the form of a Foucauldian discourse and the latter's idea that the knowledge contained in every discourse is designed to give power to someone, or, some group of people. Foucault had insisted upon the relativity of ethics and morality and had come to the conclusion that "discourses" were only consistent within their own logical parameters: it was meaningless to criticize a discourse or its view of morality and ethics from a position outside the discourse itself. In other words, the world was filled with mutually exclusive discourses and each of them could only be called "moral" in so far as the ethics and principles valued within them were accepted by the adherents of each. Criticism, from outside the parameters of the discourse, were viewed as, literally, meaningless. More sinister, was Foucault's belief that every discourse of knowledge was created in order to confer power on a particular group of people. ${ }^{\mathrm{xx}}$ In this view, Foucault was not far away from the ultimate position of Ludwig Wittgenstein who had also stressed the relativity of logic in linguistic terms: the world didn't consist of a single logic but many logics each of which operated according to its own rules.

Said, following Foucault's ideas on discourse, at one point in Orientalism makes clear how problematic it is for a discourse - in this case the discourse of "Orientalism" - to treat of "truth" in any fundamental way:

Islam has been fundamentally misrepresented in the West--the real issue is whether indeed there can be a true representation of anything, or whether any and all representations, because they are representations, are embedded first in the language and then in the culture, institutions, and political ambience of the representer. If the latter alternative is the correct one (as I believe it is), then we must be prepared to accept the fact that a representation is eo ipso implicated, intertwined, embedded, interwoven with a great many other things besides the "truth" which is itself a representation.

Of course this idea of Said's, intended as it is to undermine the West's view of Islam, also, obliquely, acts as a criticism of his own discourse against "Orientalism".

The post-colonial critic Robert J. C. Young has also emphasized the importance of Foucault to Said and to post-colonial theory in general. In his essay, "Foucault On Race and Colonialism", Young stresses the importance of Foucault's idea that every discourse represents a form of violence and a way of knowing that has more to do with the needs of a dominant ideology than any unbiased concern with some independent notion of truth.

According to Foucault, discourse always involves a form of violence in the way it imposes its linguistic order on 
the world...Following Foucault, Said argued that Orientalism was less a body of objective scholarly knowledge, than a discursive construction, whose conceptual structure determined the way in which the West understood the East. ${ }^{\text {xxviii }}$

It is easy to see then that for many of Said's supporters, in Orientalism, he had created a Foucauldian discourse that was water tight in its own terms. It applied a particular logic to the phenomenon of colonialism and the exploited peoples of the world and came up with answers that were suitable to both liberal academics and to the oppressed. Said, following Foucault, had created a discourse that related knowledge to power-and particularly Orientalist knowledge to the control of colonial lands and peoples. If anyone disagreed, let them realize the impotence of their criticisms for as long as their objections originated from a position outside the parameters of the discourse itself: such criticisms belonged to another discourse that had nothing to do with Said's. Of course, the greatest potential weakness of Said's use of the Foucauldian discourse also lies within this relativity. If Foucault is correct, then other discourses can be created with opposite conclusions to Said's - and within their own terms they too will be equally unassailable to outside criticism. Where everything is relative, no single point of view can be final. However, the higher the number of people that subscribe to a particular discourse, the more chance there is that this view will be accepted by most people as the common one.

It might usefully be added at this point, that although most Eastern and "Oriental" scholars embraced Said's vision enthusiastically, his ideas have not always been accepted with enthusiasm by Arab and Muslim intellectuals. Aijaz Ahmed, Albert Hourani and Irfan Habib have all expressed their reservations about Said's work. ${ }^{\text {xxix }}$

Of particular interest in the context of Said's Orientalist interpretation of Richard Francis Burton's life and work is Irfan Habib who has criticized Said for ignoring normal academic boundaries between subjects and regarding all academics who deal with the "Orient", whatever their discipline, as "Orientalists":

But such basic work is only incidental to Said's definition of Orientalism, which has its scope enlarged to take in the discourse of anyone who teaches about, or researches the Orient...Soon enough Said forgets the professional boundaries of teacher and researcher. Journalists, novelists and politicians appear with quiet ease on his pages as "Orientalists" wherever they have a statement to make that Said wishes to attribute to "Orientalism". xxx

Habib goes on to suggest that Said has constructed a monster which insists that all negative views of the Orient and Islam that come from the West are examples of the hated "Orientalism" and so tainted and to be ignored:

Despite Said's denials that it was not his intention to protect chauvinistic or conservative beliefs in Asia, especially in relation to Islam, one can see that any critical or historical view of any aspect of Islam by any western scholar is yet taken by him as reflective of a sense of western superiority and so a kind of 'Orientalist', colonial discourse. ${ }^{\text {xxi }}$

Habib gives the word "Mohammedan" as an example of this paranoia. He points out that in Persia innumerable Muslim scholars have, for centuries, spoken of the "Muhammedan faith" and "Muhammedan law" ("Din-i-Muhammadi" and "Shariat-i Muhammadi"). However, in the modern world (thanks to Orientalism):

[T]he word 'Mohammedan' is quickly disappearing from books, and even from titles of works by authors, long dead: thus Goldziher's Mohammedanische Studien and H A R Gibb's Mohammedanism now reappear in print respectively as Muslim Studies (English translation) and Islam in editions by established academic publishers. An innocent designation becomes disreputable the moment it is found to be tainted through association with that pernicious weed, "Orientalism". xxxii

Echoing other critics such as Lewis and Irwin, Habib makes the point that the discovery of knowledge is, in itself, without ideology. He insists that much of the scholarship dismissed by Said as "Orientalist" has made real contributions to our view of the past.

When, on page 203, Said concedes that the work of 'innumerable' Orientalists has consisted in editing and translating texts, codifying grammars, establishing lexical meanings, and reconstructing 'dead epochs', he fails to recognize that this very work, irrespective of the conservative or liberal views of the individual scholars concerned, results in continuously altering our fundamental notions of the past as well as the present. ${ }^{\text {xxxii }}$

Habib goes on to speak of I Goldziher who was an anti-Zionist Jew, who received his post-graduate university education at Al-Azhar University in Cairo and professed to have an equal respect for all three revealed, monotheistic 
religions hailing from the Middle East:

For the part of Orientalism Said closes his eyes to...such extremely influential figures as I Goldziher (a Hungarian, incidentally, not a German - contra Said, p. 18) who would hardly fit Said's perception of an 'Orientalist'. Classical master of hadis-criticism, Goldziher was an anti-Zionist Jew, who received his 'postgraduate' education at al-Azhar and professed the same critical respect for Islam as for Judaism and Christianity. Where would such a man be placed in Said's scheme? ${ }^{\text {xxiv }}$

According to Habib, Said has ignored Goldziher because he did not fit into his easy category of Orientalist/Imperialist. Of course, one reason Said was able to do this was because Goldziher is hardly well known. Richard Francis Burton, on the other hand, was a giant of the period. Said could not ignore him; so, instead, he sought to denigrate both him and his achievement (impersonally enough, it should be stated). It will be the essential aim of the next part of this discussion to illustrate the various ways in which Said misinterpreted the evidence available to construct a Richard Burton that fitted easily into his theories on "Orientalism", but did not reflect the truth about the real man.

\section{Part II}

We can say that-like almost any author of note-Burton has been regarded in different ways by biographers and interested scholars, since his death towards the end of the nineteenth century. Largely, these interpretations have been positive and generous to a man who took many risks with his own life and made many interesting and useful discoveries during the course of a comparatively long life by nineteenth-century standards. However, since the publishing of Said's theories, his reputation has, inevitably, become rather tarnished in academic circles. For example, in her book Imperial Eyes Mary Louise Pratt describes Burton as an example of the "monarch-of-all-I-survey" explorer and gives a long quotation from the latter's description of his first discovery of Lake Tanganyika. ${ }^{\text {xxv }}$ Similarly David Spurr, in his book The Rhetoric of Empire, refers to Pratt's earlier comments on Burton and the way in which "the landscape is...described so as to subordinate it to the power of the speaker." ${ }^{\text {"xxvi }}$ Here, Spurr is in concordance with both Pratt and Said in the view that Burton's "imperial eyes" in some way "subordinate" the exotic world he perceives to his own control and to the control of his imperialist masters.

In Orientalism, Said says a fair deal about Richard Burton and, in spite of a sense of Burton's superiority over most Orientalists of the time, he still finishes by placing him squarely in the imperialistic/Orientalist camp, labeling him as being perhaps all the more dangerous for his apparent individualism and sympathy for the Orient. ${ }^{\text {xxxvii }}$ This has done a disservice to the reputation of Burton who should be considered on his own terms and for his own writings and discoveries, rather than as an addendum to Said's theories on Orientalism and imperialism. In particular, Said has little or nothing to say about Burton's contribution to our modern view of religion, which is mostly seen in the West from a relativist position which lies outside the categories of faith themselves. Dane Kennedy, in his recent book, The Highly Civilized Man makes this contribution clear.

Yet even as Burton positioned himself as an exponent of 'scientific' racism, he also marshaled this understanding of racial difference as innate and immutable to challenge European universalist claims that its own civilization was unsurpassed and supplied a model for others to emulate. Because those claims were so closely bound up with Christianity, he deployed his knowledge of other systems of belief...to demonstrate that each was embedded within its own particular historical and cultural context, precluding the possibility that any single system of religion enjoyed a monopoly on truth. ${ }^{\text {xxxii }}$

Kennedy also develops this point in a highly specific way relating to Burton's inability to wholly accept the doctrines of any religion as "true":

Burton exhibited an intellectual curiosity in religions of all sorts, but this curiosity never carried over into the unquestioning commitment of the devout believer... Ironically, what motivated this catholicity of interest was his deep skepticism about any religion's claim to absolute truth. ${ }^{\text {xxix }}$

In addition to his contribution to the development of this relativist view of religion, Burton made many contributions to geography, anthropology, ethnography and the study of comparative religions-his impartiality in such matters was most clearly instanced by his own belief in the superiority of Islam over Christianity at a time when most scholars and ordinary people in the West viewed Islam as an essentially blasphemous religion appropriate only for barbarians. To this extent, Burton would seem to appear as the antithesis of the traditional Orientalist, collecting data about foreign cultures with the intention of proving his own society's views to be superior. Kennedy is enlightening on the ways in which Burton's methods and conclusions could be turned against the imperialists themselves in order to deny the absolute truth of any one religion: 
Difference became for Burton the basis for critical enquiry, capable of being turned in any direction, not least against Britain itself...Once he understood that difference itself was a neutral epistemological device, a polarity that contained no inherent meaning, he began to wield it in ways that challenged the universalist claims of British society.

From this point of view, then, it would be reductionistic to view Burton as a mere advanced servant of imperialism who happened to have a particularly good understanding of the Orientalist canon and, consequently, was in a better position than most to utilize it in the service of his Western masters. Such a view of Burton does not do justice to the genuine originality and impartiality of much of his thought, and Said's caricature of Burton's ideas and motives, as explained in Orientalism, begins to be revealed as mere polemic. On the contrary, as Kennedy suggests, many of Burton's conclusions about religion and power subtly undermined the absolutist claims of Western societies to be "right" in their dealings with colonial peoples.

Burton, of course, lived at a pivotal time for the development of new scientific methods and disciplines. The Origin of Species was published in $1859^{\text {xli }}$ and Burton was quick to declare himself a believer in evolution. ${ }^{\text {xlii }}$ Furthermore, in 1871, Edward Burnett Tylor made the study of anthropology scientific with his ground-breaking work Primitive Culture: Researches into the Development of Mythology, Philosophy, Religion, Language, Art and Custom, which immediately became the standard treatise on anthropology. ${ }^{\text {xliii }}$ Of particular importance in challenging the monotheistic faith of Victorian society was Tylor's insistence that religion was a universal activity within the family of man that was characterized by a belief in "spiritual beings". xliv Moreover, Tylor pursued his anthropological research from an evolutionist perspective, lending his powerful support to Darwin's controversial theories. ${ }^{\text {xlv }}$ These scientific, philosophical and social contexts in which Burton worked are also of significance in evaluating his very real achievements.

\section{Part III}

I will conclude with a brief look at the ways in which Burton has been viewed by scholars, academics and ordinary people from his own time right down to (and even beyond) the influential portrayal of Burton as "Orientalist" par excellence by Said towards the end of the twentieth century.

The first biography of Burton was written by his wife, Isabel, in $1893{ }^{\text {xlvi }}$ This provides a picture of Burton as seen by an adoring wife and is diminished by a wish to always show the writer in a favourable light. The manuscript ran to 1300 pages and two volumes, and Isabel refused to allow any outside influence. The book is often unwieldy and unchronological, but is inclusive of lots of information about Burton that only a wife could know about. She is also surprisingly fair-minded about Burton's religious outlook, seeming to be well aware of her husband's catholicity of tastes and fondness for Islam and Sufism.

I am by no means going to tell you that his Catholicity was a life-long, fixed and steady thing, like mine. It was not. He had long and wild fits of Eastern Mysticism, but not the Agnosticism that I have seen in England since my widowhood. It was the mysticism of the East-Sufism. Periodically he had Catholic fits, and practiced it, hiding it sometimes even from me, though I knew it.

Isabel goes on to suggest how even Burton's intimate friends would not have agreed on his faith:

Most of his intimate friends are dead but there are still a few left ... who might possibly write sections of his life. ... One would describe him as a Deist, one as an Agnostic, and one as an Atheist and Freethinker, but I can only describe the Richard that I knew, not the Richard they knew. I, his wife, who lived with him day and night for thirty years, believed him to be half-Sufi, half Catholic. ${ }^{\text {xlviii }}$

Isabel's biography of her husband was published on 11 July 1893. Most of the reviews were positive, agreeing with the opinion of the Edinburgh Review that "this is a very extraordinary book, by a very extraordinary woman about a very extraordinary man." "xlix Fawn M. Brodie, in her biography of Burton, The Devil Drives, is more ambivalent in her assessment of Isabel's great "source" book:

Although she professed to admire Richard as 'a spade-truth man,' she held rigorously to the rule she had set for herself at marriage, 'Hide his faults from everyone'.

Only a few months after Isabel's death, Burton's niece, Georgiana Stisted, came out with a second biography that aimed at rectifying what she believed to be Isabel's distortions and lies. In particular, she wished to distance her uncle from the Catholic Church and to upbraid the wife for her destruction of substantial parts of Burton's writing after his death. As Kennedy comments: 
The distinguishing intent of this biography was to wrench the memory of Georgiana's uncle from the clutches of his widow, a woman she described as suffering from a "fatal want of tact and judgment", and, by extension, from the Catholic Church, which she regarded as a haven of "human folly and superstition".

Leaving aside Stisted's view of the marriage, the issue of Burton's religious position is obviously important.

Other biographies appeared on a fairly regular basis in the years that followed. Most of these concentrated on the figure of Burton as a brave adventurer in Arabian lands, possessing titles such as, Burton: Arabian Nights Adventurer (1931), The Arabian Night (1936), and Death Rides a Camel (1936). The first of these, by Thomas Wright and published in 1906, created a storm by its contention that most of Burton's translation of the Nights was stolen from John Payne. Robert Irwin in his The Arabian Nights: A Companion is skeptical about this. ${ }^{\text {liii }}$ Certainly the accusation infuriated the remaining members of Burton's family (mostly cousins). The fact that Burton had been collecting manuscripts from the Nights' stories and translating them for twenty five years before he ever met Payne (and while journeying all over the world), would seem to disprove Wright's theory. Moreover, Wright did not speak Arabic and was hardly in a position to expertly judge.

Subsequent biographies of Burton were more in the accepted mold of unstinting praise for an English hero. Dane Kennedy writes:

The adventurous man of action would become the most popular and enduring of the many representations of Burton. It sustained a steady stream of biographies, supplying vicarious thrills for those who sought imaginative release from the monotonous confines of modern urban society. ${ }^{\text {liv }}$

And Kennedy is surely right when he suggests that Burton the adventurer has served as the model for many individuals who wanted to experience the same adventures and deprivations as their hero.

Harry St. John Philby sought to model himself after Burton . . . Wilfred Thesiger allowed himself to imagine he was back in Burton's days. . . . More recently, the Canadian financier and philanthropist Christopher Ondaatje and the English novelist and travel writer Bruce Chatwin have drawn inspiration from Burton in their efforts to conjoin authorship and adventure.

Kennedy makes the point that amongst the hagiography, many essential elements of Burton's character were overlooked: his love of Islam, his anti-semitism, his racism and his ecumenical interest in religions of all sorts. ${ }^{\text {lvi }}$

Since the war and changes in the laws concerning public decency, ${ }^{\text {lvii }}$ much attention has been given to Burton's sexual writings, and his Kama Sutra and Arabian Nights remain popular translations to this day, despite the somewhat archaic language. After the war, Burton was given much credit for his journeys in Africa to find the source of the Nile. The BBC production "The Search for the Nile" (1971) sparked renewed interest in Burton's role in this regard (as well as narrating a compelling personal drama in terms of Burton's rivalry with Speke).

More recently have come the biographies of Fawn M. Brodie, The Devil Drives (1967), Edward Rice, Captain Sir Richard Francis Burton (1990), and Mary S. Lovell, A Rage to Live (1998). ${ }^{\text {lvii }}$ The first of these, Fawn M. Brodie's biography, devotes a lot of attention to psycho-analyzing Burton. Although it can now appear a little dated in its determination to get to the bottom of Burton's sexual character, many of the insights seem just (especially those that speak of Burton's relationship with his wife, Isabel). Edward Rice's is a most thorough and detailed biography, sometimes marred by his tendency to view Burton from the point of view of a twentieth-century hashish-taking adventurer. One of its major flaws is that many of Rice's conjectures about Burton's sexual appetite and amorous adventures are put forward as if they were facts. On the other hand, Rice is very good on the early Burton as an officer in Sind, and he puts forward convincing (if far from conclusive) evidence that as a young man Burton, very likely, viewed himself as a Sufi Muslim. However, this insight is also marred by Rice's tendency to make conjecture seem like fact.

Perhaps the most satisfying recent biography of Burton has been Mary Lovell's A Rage to Live. ${ }^{\text {lix }}$ This is a vast and most meticulously researched biography that re-establishes Isabel as an essential ingredient to any true intellectual understanding of Burton's life. Kennedy enthusiastically calls this "The most impressively researched and reliable life of Burton". " Lovell's work is based on primary materials not available to earlier biographers. In spite of this advantage her biography, although exhaustive, remains undogmatic.

Most of these latter biographies were written by American scholars and it is informative to note how the more interesting research on Burton, at least for the present, is coming from over the Atlantic. Perhaps Burton's understanding for Arab lands is of particular relevance today when much of America's foreign policy has its most important terms of reference in the Middle East.

The last significant work on Burton, though not a biography as such, is also written by an American. Dane Kennedy's The Highly Civilized Man was published in 2005. Kennedy is a historian at George Washington University and uses 
Burton as an important and seminal figure of the nineteenth century to better understand this period of British imperialism and the emergence of a scientific view of reality. He is particularly interested in Burton as an intellectual relativist who did much to help develop the modern day scientific attitude to phenomena. Unlike many previous writers on Burton, Kennedy does not turn away from confronting Burton's racism and anti-semitism, seeing them as manifestations of some wrong-headed relativist thinking (primarily the need to categorize and judge). ${ }^{\text {xi }}$

The most important late-twentieth-century view of Burton I have left until last, though some aspects of it were touched upon earlier. This is the view of Burton espoused by Said in Orientalism. Unlike the other scholars we have looked at, Said doesn't concern himself too much with Burton's life and achievements in any direct way. Rather, as I suggested earlier, he fits Burton into a supporting role within his own theory of "Orientalism”. As Said's book has proved far more influential than any of the biographies (or other books) we have looked at so far, ${ }^{\text {1xii }}$ it might reasonably be asserted that it is his view of Burton that has come to dominate--and in my view, unfairly--present day discussions about Burton and his work's significance. We earlier looked at Said's ideas in brief, but now it is necessary to examine his views on Orientalism and Burton's place within it in more detail and depth.

Said's book on Orientalism was first published in 1978, but since then it has been reprinted many times. It has, furthermore, become very much a seminal text for those post-colonial critics such as Homi K. Bhabha and Robert Young whose concern has been to look at the ways in which the world and its ideologies have become fragmented in the post-imperialist period. ${ }^{\text {lxiii }}$

The basic premise of Orientalism (which, simply put, is the profound bias of Western knowledge about the Orient) is accepted as 'true' from the beginning and all the details arranged in such a way as to support the broad argument. As a result, thanks to Said, Burton is most usually viewed as a brilliant Orientalist scholar whose peculiar but undeniably effective methods and actions were put at the service of his imperialist masters (as we have earlier seen in the views of Pratt and Spurr). I feel that this is an over-simplified view of a highly ambiguous figure: Burton was undoubtedly his own man and by no means an imperialist puppet. Said begins by noting the positive aspects of Burton:

As a traveling adventurer Burton conceived of himself as sharing the life of the people in whose lands he lived. Far more successfully than T.E. Lawrence, he was able to become an Oriental; he not only spoke the language flawlessly, he was able to penetrate to the heart of Islam and, disguised as an Indian Muslim doctor, accomplish the pilgrimage to Mecca. Yet Burton's most extraordinary characteristic is, I believe, that he was preternaturally knowledgeable about the degree to which human life in society was governed by rules and codes...So what we read in his prose is the history of a consciousness negotiating its way through an alien culture by virtue of having successfully absorbed its systems of information and behavior. ${ }^{\text {lxiv }}$

Having described Burton's Pilgrimage as "the history of a consciousness negotiating its way through an alien culture", Said then argues that Burton's absorption of the systems of information (and) behavior of this culture "elevates Burton's consciousness to a position of supremacy over the Orient". $1 \mathrm{xv}$

Said's description of Burton's 'preternatural knowledge' and his absorption of the culture's 'systems of information' are made to sound like the categorizing Orientalist method itself. However, it could just as easily be interpreted (and in my view, also more accurately) as an early attempt by a relativist to help define a scientific method of enquiry. I would go so far as to say that while there is indisputable truth in Said's view of Orientalism (and Burton's role within both it and the process of British colonization) as something that grew up and was perpetuated in the context of Western dominance over the East, it might also be seen (on a grander scale) as part of the crystallization of 'systems of knowledge' into a new and relativistic scientific method of enquiry (which was gathering pace in the late nineteenth century and beginning to threaten long-held religious views - and not without generating much controversy).

Burton, in my opinion, is better judged from this latter perspective rather than from the somewhat narrow "Orientalist" view which results in him being categorized as a mere soldier of fortune, living off his wits, in the service of his imperialist masters. Undoubtedly, Said's position on Burton (as well as that of many of his subsequent followers) is unconvincing in several ways. Burton, for example, was by no means the chameleon Said suggests, effortlessly fitting in during his journeys around the world due to his understanding of society's "codes" and "rules". His dismissal from the Damascus consulship for hot-headedness, and his extreme discomfort as a student at Oxford due to his continental manners, clearly demonstrate this. More importantly, and as we have seen, Said ignores Burton's very real contributions to Victorian knowledge and to the development of the scientific method. However, such an interpretation does enable Said to-wrongly, in my opinion-position Burton clearly within and as a part of the great Orientalist conspiracy.

\section{Conclusion}

To summarize, I would contend that the Burton Said created in his book Orientalism was a pantomime monster, totally lacking the subtlety and complexity of the real man. In consequence of this and of the subsequent demonization of Burton by post-colonialist critics who followed Said's lead on the matter, Burton, although still much admired by ordinary readers and biographers, has unfairly become something of a pariah in serious academic circles. It is my modest hope that this article might make at least a small contribution to the redressing of the balance. 


\section{References}

\section{a) First Editions of Burton's Works}

Burton, Richard Francis, ed. and trans. The Book of the Thousand Nights and a Night. With Introduction Explanatory Notes on the Manners and Customs of Moslem Men and a Terminal Essay upon the History of the Nights. Printed by the Kama Shastra Society For Private Subscribers Only. Printed in 10 volumes, 1885.

Burton, Richard Francis, ed. and trans. The Supplemental Nights to the Book of a Thousand Nights and a Night. Printed by the Kama Shastra Society For Private Subscribers Only. Printed in 6 volumes, 1886-1888.

Burton, Richard Francis. First Footsteps in East Africa. London: Longman, Brown, Green, and Longmans, 1856.

Burton, Richard Francis. The Gold-Mines of Midian and the Ruined Midianite Cities. London: C. Kegan Paul \& Co., 1878.

Burton, Richard Francis. The Jew The Gypsy and El Islam. London: Hutchinson \& Co., 1898.

Burton, Richard Francis (with F.F. Arbuthnot). The Kama Sutra of Vatsayana. London: Kama Shastra Society, 1883.

Burton, Richard Francis. The Kasidah of Haji Abdu El-Yezdi a Lay of the Higher Law. London: Bernard Quaritch, 1880 .

Burton, Richard Francis. The Lake Regions of Central Africa, A Picture of Exploration. London: Longman, Green, Longman, and Roberts, 1860.

Burton, Richard Francis. The Land of Midian Revisited. London: C. Kegan Paul \& Co., 1878.

Burton, Richard Francis, ed. and trans. The Perfumed Garden of the Cheikh Nefzaoui, A Manual of Arabian Erotology (XVI. Century). London: Kama Shastra Society of London and Benares and for private circulation only, 1886.

Burton, Richard Francis. Personal Narrative of a Pilgrimage to El-Medinah and Meccah. First edition in 3 volumes. London: Longman, Brown, Green, Longmans, and Roberts, 1855-56.

Burton, Richard Francis. Stone Talk. London: Hardwicke, 1865.

\section{b) Other Editions of Burton's Works}

Burton, Richard Francis. First Footsteps in East Africa. New York: Dover Edition, 1987.

Burton, Richard Francis. The Gold Mines of Midian. New York: Dover Publications, 1995.

Burton, Richard Francis. The Land of Midian (Revisited). Volumes I \& II, C. London: Kegan Paul \& Co., 1879.

Burton, Richard Francis. The Perfumed Garden. New York: Park Street Press, 1992.

Burton, Richard Francis. The Pilgrimage to Makkah and Medina. New Delhi, India: Goodword Books, za, 2002.

Burton, Richard Francis. The Sotadic Zone. Amsterdam, The Netherlands: Fredonia Books, 2002.

\section{c) Works About Burton}

Brodie, Fawn M. The Devil Drives. New York: W.W. Norton and Company Inc., 1984.

Burton, Isabel. The Life of Richard Burton. London: Chapman and Hall, 1893.

Dearden, Seton. The Arabian Night. London: Barker, 1953.

Dodge, Walter. The Real Sir Richard Burton. Londo: Unwin, 1907.

Downey, Fairfax. Arabian Nights' Adventurer. London: Scribner, 1931.

Farwell, Byron. Burton: A Biography of Sir Richard Francis Burton. London: Longmans, 1990.

Kennedy, Dane. The Highly Civilized Man. Boston: Harvard University Press, 2005.

Lovell, Mary S. A Biography of Richard and Isabel Burton. New York: W.W. Norton and Co., 2000.

McLynn, Frank. Snow Upon the Desert. London: Murray, 1993.

Rice, Edward. Captain Sir Richard Francis Burton: A Biography. Cambridge, MA: Da Capo Press, 2001.

Stisted, Georgina. The True Life of Sir Richard Francis Burton. London: H.S. Nicholls, 1896.

Wright, Thomas. Sir Richard Burton. 2 Vols. London Everett, 1906.

\section{d) Background Reading}

Aijaz, Ahmed. In Theory: Classes, Nations, Literatures. London: Verso, 1992.

Barthes, Roland. Elements of Semiology. (trans. Annette Lavers and Colin Smith). London: Jonathan Cape, 1967.

Barthorp, Michael and Gerry Embleton. Napoleon's Egyptian Campaigns1798-1801. London: Osprey Publishing, 1992. 
Baussier, Sylvie. Champollion et le Mystere des hieroglyphes. Paris: Sorbier, 2002.

Bell, Gertrude. Diaries The Arabian, 1913-1914. Syracuse, NY: Syracuse University Press, 2000.

Bell, Gertrude. The Desert and the Sown: The Syrian Adventures of the Female Lawrence of Arabia. New York: Cooper Square Press, 2001.

Bell, Gertrude. Gertrude Bell: Queen of the Desert, Shaper of Nations. New York: Farrar, Strauss and Giroux, 2008.

Bhabha, Homi K. The Location of Culture. London: Routledge, 2004.

Bhabha, Homi K. Nation and Narration. London: Routledge, 1990.

Bloom, Harold. Deconstructionism and Criticism. New York: Seaberry Press, 1979.

Boheemen, Christine van. Joyce, Derrida, Lacan and the Trauma of History: Reading, Narrative, and Postcolonialism. London: Cambridge University Press, 2006.

Browne, Janet. Darwin's Origin of Species. New York: Atlantic Monthly Press, 2007.

Burckhardt, John Lewis. Notes on the Bedouins and Wahabys. 2 Vols. Southern Arabia: Folios Archive Library, 1993.

Burckhardt, John Lewis. Travels in Arabia. Lenox, MA: Hard Press, 2006.

Burleigh, Nina. Mirage: Napoleon's Scientists and the Unveiling of Egypt. New York: HarperColllins, 2007.

Cannadine, Dennis. Ornamentalism How the British Saw Their Empire. Boston: Oxford University Press, 2002.

Caracciolo, Peter R. The Arabian Nights in English Literature. London: St. Martin’ Press, 1988.

Carrier, James. (ed.). Occidentalism: Images of the West. London: Clarendon Press,1995.

Chandler, David G. The Campaigns of Napoleon. New York: Scribner, 1973.

Cole, Juan. Napoleon's Egypt: Invading the Middle East. New York: Palgrave MacMillan, 2007.

Crinson, Mark. Empire Building: Orientalism and Victorian Architecture. New York: Routledge, 1996.

Culler, Jonathan. The Pursuit of Signs: Semiotics, Literature, Deconstruction. London: Routledge, 1981.

Culler, Jonathan. Structuralist Poetics: Structuralism, Linguistics and the Study of Literature. London: Routledge \& Kegan Paul, 1975.

Darwin, Charles. The Origin of Species. London: John Murray, 1859.

Davies, Kristian. Orientalists: Western Artists in Arabia, the Sahara, Persia and India. New York: Laynfaroh, 2006.

Davoli, Michel and Paola Dewachter. Champollion e il Contributo Italiano Alla Riscoperta Dell'Antico Egitto. Comune di Rimini and Museo della Citta' Italia, 1991.

Derrida, Jacques. Of Grammatology. (trans. Gayatri Chakravorty Spivak). Baltimore: John Hopkins University Press, 1976.

Dobie, Madeleine. Foreign Bodies: Gender, Language, and Culture in French Orientalism. Stanford, CA: Stanford University Press, 2001.

Doughty, Charles M. Travels in Arabia Deserta: Selected Passages. New York: Dover Publications, 2003.

Eagleton, Terry. Literary Theory. London: Blackwell, 1983.

Eco, Umberto. Semiotics and the Philosophy of Language. Indianapolis: Indiana University Press, 1984.

Edney, Matthew H. Mapping an Empire: The Geographical Construction of British India1765-1843. Chicago: University of Chicago Press, 1999.

Ellis, Havelock. Studies in the Psychology of Sex, Volume 2: Sexual Inversion. Charleston, SC: Bibliobazaar, 2007.

Esposito, John L. (ed.). The Oxford History of Islam. London: Oxford University Press, 2000.

Fanon, Frantz. Black Skin White Masks. New York: Grove Press, 1967.

Fanon, Frantz. The Wretched of the Earth. New York: Grove Press, 1961.

Flower, Raymond. Napoleon to Nasser: The Story of Modern Egypt. New York: 1st Books Library, 2002.

Foucault, Michel. The Archaeology of Knowledge and the Discourse on Language. (trans. A.M. Sheridan Smith). New York: Pantheon, 1972.

Foucault, Michel. Discipline and Punish: the Birth of the Prison. (trans. Alan Sheridan). New York: Pantheon, 1978.

Foucault, Michel. The History of Sexuality, Vol. 1: An Introduction. (trans. Robert Hurley). New York: Pantheon, 1978.

Foucault, Michel. Madness and Civilization: A History of Insanity in the Age of Reason. (trans. Richard Howard). New York: Pantheon, 1965.

Gallagher, Nancy Elizabeth. Approaches to the History of the Middle East:Interviews with Leading Middle East Historians. Ithaca, NY: Ithaca Press, 1997.

Galland, Antoine. Le mille e une nuits. Paris: Classiques Garnier, 1988.

Gandhi, Leila. Postcolonial Theory: A Critical Introduction. New York: Columbia University, 1998. 
Gauch, Suzanne. Liberating Shahrazad: Feminism, Postcolonialism and Islam. Minneapolis, MN: University of Minnesota Press, 2006.

Geniesse, Jane. Passionate Nomad: The Life of Freya Stark. New York: Modern Library, 2001.

Gerhardt, Mia. The Art of Story-Telling: A Literary Study of the Thousand and One Nights. Boston: E.J. Brill, 1963.

Ghazoul, Ferial. Nocturnal Poetics: The Arabian Nights in Comparative Context. Cairo, Egypt: American University in Cairo Press, 1996.

Grant, Ben. Postcolonialism, Psychoanalysis and Burton: Power Play of Empire. New York: Routledge, 2008.

Haddawy, Hussein. The Arabian Nights. New York: W.W. Norton, 2008.

Harris, Roy. Reading Saussure. London: Duckworth, 1987.

Headrick, Daniel R. The Tools of Empire: Technology and European Imperialism in the Nineteenth Century. New York: Oxford University Press, 1981.

Helms, Mary W. Ulysses' Sail: An ethnographic Odyssey of Power, Knowledge, and Geographical Distance. Princeton, NJ: Princeton University Press, 1988.

Hobson, John Atkinson. Imperialism: A Study. New York: Cosimo Classics, 2006.

Hourani, Albert. Islam in European Thought. London: Cambridge University Press, 1992.

Irwin, Robert. The Arabian Nights: A Companion. London: Tauris Parke Paperbacks, 2008.

Irwin, Robert. For Lust of Knowing: the Orientalists and their Enemies. London: Allen Lane, 2006.

Irwin, Robert. Dangerous Knowledge: Orientalism and its Discontents. New York: Overlook, 2008. Ivison, Duncan. Postcolonial Liberalism. Boston: Cambridge University Press, 2002.

Jacobs, Jane M. Edge of Empire: Postcolonialism and the City. London: Routledge, 1996.

Kalchuri, Bhau. Meher Prabhu. Meherabad, India: Manifestation, 1998.

Khan, Aga. The Memoirs of the Aga Khan: World Enough and Time. London: Cassel and Company, 1954.

King, Richard C. Postcolonial America. Urbana, IL: University of Illinois Press, 2000.

Kontje, Todd. German Orientalisms. Ann Arbor: University of Michigan Press, 2004.

Kramer, Martin S. Ivory Towers on Sand. Washington, DC: Washington institute for Near East Policy, 2001.

Lacan, Jacques and Anthony Wilden. The Language of the Self: The Functions of Language in Psychoanalysis. Baltimore: John Hopkins University Press, 1968.

Lane, Edward. The Arabian Night's Entertainments--Or the Thousand and One Nights. London: Tudor Publishing, 1927.

Lane, Edward. An Account of the Manners and Customs of the Modern Egyptians: Volume 1. London: Charles Knight and Co., 1836.

Lawrence, T.E. Seven Pillars of Wisdom. New York: Random House, 1991.

Lewis, Bernard. The Arabs in History. New York: Oxford University Press, 2002.

Lewis, Bernard. Islam and the West. New York: Oxford University Press, 1994.

Lewis, Bernard. The Middle East. New York: Scribner, 1997.

Lewisohn, Leonard and Christopher Shackle. Attar and the Persian Sufi Tradition: The Art of Spiritual Flight. London: Institute for Ismaili Studies, 2007.

Lodge, David. Working with Structuralism. London: Routledge \& Kegan Paul, 1981.

Loomba, Ania. Colonialism/Postcolonialism. New York: Routledge, 1998.

Lovell, Mary S. A Scandalous Life: The Biography of Jane Digby. London: Fourth Estate, 2003.

Marcus, Steven. The Other Victorians: A Study of Sexuality and Pornography in Mid-Nineteenth-Century England. New York: Transaction Publishers, 2008.

Marx, Karl and David McLellan. Capital: An Abridged Edition. New York: Oxford University Press, USA, 1999.

Marx, Karl. (trans. Ben Fowkes). Capital, Vol. 1. London: Penguin, 1990.

Mason, Michael. The Making of Victorian Sexuality. New York: Oxford University Press, 1995.

Meyerson, Daniel. The Linguist and the Emperor: Napoleon and Champollion's Quest to Decipher the Rosetta Stone. New York: Random House, 2005.

Morrissey, Katherine G. Mental Territories: Mapping the Inland Empire. Ithaca, NY: Cornell University Press, 1997.

Murray, John. Mythology, Philosophy, Religion, Art and Custom, Volumes 1 \& 2. London: John Murray, 1871.

Nasr, Valli. The Shia Revival: How Conflicts Within Islam Will Shape the Future. New York:W.W. Norton, 2006.

Ouyang, W. New Perspectives on Arabian Nights. London: Routledge, 2005. 
Palgrave, W.G. Personal Narrative of a Year' Journey Through Central and Eastern Arabia 1862-1863. 2 Vols. London: Macmillan and Co., 1865.

Pakenham, Thomas. The Scramble for Africa: White Man's Conquest of the Dark Continent from 1876-1912. New York: Avon Books, 1992.

Parkinson, Richard. Cracking Codes: The Rosetta Stone and Decipherment. Los Angeles: University of California Press, 1999.

Payne, John. Tales from the Arabic: Of the Breslau and Calcutta (1814-1818) of the Book of the Thousand Nights and One Night. Printed For Subscribers Only, London, 1884.

Phillipson, Robert. Linguistic Imperialism. New York: Oxford University Press, 1992.

Pinker, Steven. How the Mind Works. New York: W.W. Norton, 1999.

Pinker, Steven. The Language Instinct: How the Mind Creates Language. New York: Harper Perennial Modern Classics, 2007.

Plato. Plato Complete Works. (eds.) John M. Cooper and D. S. Hutchinson, Indianapolis, IN: Hackett Publishing Company, 1997.

Pratt, Mary Louise. Imperial Eyes: Travel Writing and Transculturation. New York: Routledge, 1993.

Pratt, Mary Louise. Toward a Speech Act Theory of Literary Discourse. Indianapolis: Indiana University Press, 1977.

Prichard, James Cowles. Researches into the Physical History of Man. Chicago: University of Chicago Press, $1813 / 1973$.

Reid, Donald Malcolm. Whose Pharaohs?: Archaeology, Museums, and Egyptian National Identity from Napoleon to World War 1. Los Angeles: University of California Press, 2003.

Ridley, Ronald T. Napoleon's Proconsul in Egypt: The Life and Times of Bernardino Drovetti. London: Rubicon Press, 1998.

Robinson, Peter (ed.). Calmets Dictionary of the Holy Bible. London: Samuel Etheridge, 1812.

Rose, Steven. The 21st Century Brain. Londin: Vintage Books, 2006.

Rosenman, Ellen Bayuk. Unauthorized Pleasures: Accounts of Victorian Erotic Experience. Ithaca, NY: Cornell University Press, 2003.

Rosenthal, Donald A. Orientalism, the Near East in French Painting, 1800-1880.

Rochester, NY: Memorial Art Gallery of the University of Rochester, 1982.

Russell, Terence M. The Discovery of Egypt: Vivant Denon's Travels with Napoleon's Army. Washington, DC: The History Press, 2005.

Said, Edward W. Covering Islam. New York: Random House, 1997.

Said, Edward W. Culture and Imperialism. New York: Vintage Books,k, 1994.

Said, Edward W. Humanism and Democratic Criticism. New York: Columbia University Press, 2004.

Said, Edward W. Orientalism. New York: Vintage Books, 1979.

Said, Edward W. The Politics of Dispossession: The Struggle for Palestinian Self Determination, 1969-1994. New York: Random House, 1995.

Said, Edward W. Power, Politics, and Culture: Interviews with Edward W. Said. New York: Random House 2001.

Said, Edward W. Reflections on Exile and Other Essays. Boston: Harvard University Press, 2002.

Said, Edward W. The World, the Text, and the Critic. Boston: Harvard University Press, 1983.

Saunders, John J. A History of Medieval Islam. London: Routledge, 1978.

Saussure, Ferdinand de. Course in General Linguistics. (trans. Wade Baskin), London: Fontana/Collins, 1974.

Shaheen, Jack G. Reel Bad Arabs: How Hollywood Vilifies a People. New York: Interlink, 2001.

Sharafuddin, Mohammed. Islam and Romantic Orientalism: Literary Encounters with the Orient. Londn: I.B. Tauris, 1994.

Spencer, Herbert. The Principles of Biology. 2 Vols. Lodon: William and Norgate, 1864.

Spivak, Gayatri Chakravorty. A Critique of Postcolonial Reason: Toward a History of the Vanishing Present. Boston: Harvard University Press, 1999.

Spivak, Gayatri Chakravorty. In Other Worlds: Essays in Cultural Politics. New York: Routledge, 2006.

Spurr, David. The Rhetoric of Empire: Colonial Discourse in Journalism, Travel Writing, and Imperial Administration. Durham, NC: Duke University Press, 1993.

Stark, Freya. The Southern Gates of Arabia: A Journey in the Hadhramaut. New York: Modern Library, 2001.

Steegmuller, Francis. Flaubert in Egypt: A Sensibility on Tour. Boston: Little, Brown and Co., 1973. 
Stocking, George. Victorian Anthropology. New York: Free Press, 1991.

Strathern, Paul. Napoleon in Egypt. New York: Bantam, 2008.

Swinburne, Algernon Charles. The Cannibal Catechism. Printed privately, London, 1913.

Syrotinski, Michael. Deconstruction and the Postcolonial: At the Limits of Theory. London: Liverpool University Press, 2007.

Thesiger, Wilfred. A Vanished World. New York: W.W. Norton \& Company, 2002.

Thesiger, Wilfred. Arabian Sands. Ne York: Penguin, 2007.

Thesiger, Wilfred. The Marsh Arabs. New York: Penguin, 2008.

Tucker,Herbert F. A Companion to Victorian Literature and Culture (Blackwell Companions to Literature and Culture). Upper Saddle River, NJ: Wiley-Blackwell, 1999

Turner, Bryan S. Orientalism, Postmodernism and Globalism.New York: Routledge, 1994.

Tylor, Edward Burnett. Primitive Culture: Researches into the Development of Mythology, Philosophy, Religion, Art and Custom. Volumes 1 \& 2. London: John Murray, 1872.

Varisco, Daniel Martin. Reading Orientalism: Said and the Unsaid. Seattle, WA: University of Washington Press, 2007.

Walkowitz, Judith R. Prostitution and Victorian Society: Women, Class, and the State .Boston: Cambridge University Press, 1982.

Walter. My Secret Life. Privately printed in 11 volumes, Amsterdam, 1888.

Warraq, Ibn. Defending the West: A Critique of Edward Said's Orientalism. New York: Prometheus Books, 2007.

Williams, Raymond. The Country and the City. London: Hogarth Press, 1985.

Williams, Raymond. Culture and Society, 1780-1950. New York: Columbia University Press,1983.

Williams, Raymond. Keywords: A Vocabulary of Culture and Society. London: Fontana Paperbacks, 1983.

Williams, Raymond. The Long Revolution. London: Broadview Press, 2001.

Williams, Raymond. Marxism and Literature. London: Oxford University Press, 1977.

Wittgenstein, Ludwig. Philosophical Investigations. Upper Saddle River, NJ: Prentice Hall, 1973.

Young, Robert. Colonial Desire: Hybridity in Theory, Culture and Race. London:Routledge, 1995.

Young, Robert. The Idea of English Ethnicity. London: Wiley-Blackwell, 2007.

Young, Robert. Postcolonialism: A Very Short Introduction. New York: Oxford University Press, 2003.

Young, Robert. Postcolonialism: An Historical Introduction. San Francisco: Wiley-Blackwell, 2001.

Young, Robert. White Mythologies: Writing History and the West. London: Routledge, 1993.

\section{e) Selected Articles}

Habib, Irfan. "Critical Notes on Edward Said." International Socialism: A Quarterly Journal of Socialist Theory. 17 October, 2005: 1-6.

Jassanoff, Maya. "Before and After Said.” London Review of Books. 8 June, 2006: 1-8.

Lewis, Bernard. “The Question of Orientalism.” The New York Review of Books 29. 24 June 1982: 49-56.

\section{Notes}

${ }^{i}$ Edward W. Said, Orientalism (New York: Vintage, 1979) xix.

ii Orientalism xx.

iii Orientalism xxi-xxii.

${ }^{\text {iv }}$ Mary Louise Pratt, Imperial Eyes: Studies in Travel Writing and Transculturation(London: Routledge, 1992) 4.

${ }^{v}$ See L.P. Harvey, Ibn Battuta (Makers of Islamic Civilization) (London: I.B.Tauris, 2008) 5: "It is impossible to state with any certainty when precisely the narrative of the Travels began to take shape orally, but with some confidence we may say that the version we have began to come together when, having returned to his native Morocco, after traversing virtually every country then known to Muslims and on occasions adventuring beyond the bounds of that known world, Ibn Battuta recounted at the court of Abu 'Inan in Fez the wonders he had seen. Ibn Juzayy who wrote it all down for Ibn Battuta, did so under orders from Abu 'Inan".

${ }^{\mathrm{vi}}$ Mary W. Helms, Ulysses' Sail: An Ethnographic Odyssey of Power, Knowledge, and Geographical Knowledge (Princeton: Princeton University Press, 1988) 78-80.

vii Robert J.C Young, White Mythologies (New York, Routledge, 2004). 
viii Young 132-133.

ix Orientalism, 314-321.

“ Bernard Lewis, "The Question of Orientalism", The New York Review of Books, 24 June 1982. This article is of intrinsic interest due to its appearance just a few years after Said's book and also because of its attempt to provide a rebuttal of Orientalism's argument by the one "Orientalist" who had probably come in for the most scathing criticism of all by Said.

xi Lewis 3.

xii Although the Rosetta stone was later expropriated by the British and put on display in the British Museum, it was a Frenchman, Jean-Francois Champollion who was most influential in eventually breaking the hieroglyphic code. For a full consideration of Champollion's achievement in its historical context see: Daniel Meyerson, The Linguist and the Emperor: Napoleon and Champollion's Quest to Decipher the Rosetta Stone (New York: Random House, 2005).

xiii See Albert Hourani, Islam in European Thought (Cambridge: Cambridge University Press, 1992) 1. "From the time it first appeared, the religion of Islam was a problem for Christian Europe. Those who believed in it were the enemy on the frontier...The relationship between Muslims and European Christians, however, was not simply one of holy war, of crusade and of jihad. There was trade across the Mediterranean, and the balance of it changed in course of time; from the eleventh and twelfth centuries onwards the Italian ports expanded their trade, and, in the fifteenth and sixteenth centuries, ships from the ports of Northern Europe began to appear in the Mediterranean and the Indian Ocean."

xiv Lewis, “The Question of Orientalism”, p. 9.

${ }^{\mathrm{xv}}$ Martin S. Kramer, Ivory Towers on Sand: The Failure of Middle Eastern Studies in America (Washington, DC: Washington Institute for Near Eastern Studies, 2001).

xvi It is perhaps surprising that at the time of writing, no important biography of Said has yet appeared. In his own recollection of his early years, Said makes plain the privileged nature of his upbringing (even if he does this unconsciously): "Our family home was in Talbiyah, a part of West Jerusalem that was sparsely inhabited but had been built and lived in exclusively by Palestinian Christians like us: the house was an imposing two-story stone villa with lots of rooms and a handsome garden in which my two youngest cousins, my sisters, and I would play.” See Edward W. Said, Out of Place: A Memoir (New York: Vintage, 2000) 21.

xvii Kramer 27-28.

xviii Kramer 29.

xix "Post-colonialism . . . deals with the effect of colonization on cultures and societies. As originally used by historians after the Second World War in terms such as the post-colonial state, "post-colonial" had a clearly chronological meaning, designating the postindependence period. However, from the late 1970s the term has been used by literary critics to discuss the various cultural effects of colonization.” See, Bill Ashcroft, Gareth Griffiths and Helen Tiffin, Post-Colonial Studies: the Key Concepts (New York: Routledge, 2000) 186.

xx Kramer 31 .

${ }^{x x i}$ Robert Irwin, Dangerous Knowledge: Orientalism and its Discontents (New York: Overlook Press, 2006).

xxii Scott McLemee, "What Said Said", Inside Higher Education, 13 December, 2006 http://www.hartfordhwp.com/archives/10/143.html.

xxiii McLemee, "What Said Said".

xxiv Maya Jasanoff, "Before and After Said”, London Review of Books, 8 June, 2006.

xxv These ideas of Foucault's are mostly worked out in The Order of Things: An Archaeology of the Human Sciences (New York: Vintage, 1973), The Archaeology of Knowledge (London: Tavistock, 1977), and Discipline and Punish: The Birth of the Prison (London: Penguin Press, 1977). Mary Louise Pratt also seems to have been influenced by Foucault. In Imperial Eyes, she speaks of "Redundancy, discontinuity, and unreality. These are some of the chief coordinates of the text of Euroimperialism, the stuff of its power to constitute the everyday with neutrality, spontaneity, numbing repetition" (2). This seems very close to the project outlined by Foucault in his Archaeology of Knowledge where he insists traditional history has concentrated on great events to the exclusion of the myriad personal histories which would give a very different view of the past.

${ }^{x x v i}$ In Philosophical Investigations, Wittgenstein rejected his earlier idea that language and reality shared a common logic. Instead, he propounded the view that reality and language is made up of many different logics. For example, he gives the story of the young boy who takes a shopping list from his mother to the local store. When the shopkeeper reads the note it says: "Three red apples". In order to fulfill this simple order, the shopkeeper must know what an apple is, be able to distinguish the colour red from all other colours and, finally, be able to count. The point is, that even in such a simple sentence, three different kinds of logic are being employed.

xxvii Orientalism 272.

xxviii Robert J. C. Young, "Foucault on Race and Colonialism", 13 Mar.2008. $\leq$ http://robertjcyoung.com/Foucault.pdf $>$ In this essay, Young also berates Foucault for his Franco-Centric view of the world.

xxix See "Interviews with Albert Hourani" in Nancy Elizabeth Gallagher, Approaches to the History of the Middle East (London: Ithaca Press, 1994) 40-41. Aijaz Ahmed, like Hourani, thought "that when the dust of current literary debates settles, Said's most enduring contribution will be seen as residing neither in Orientalism, which is a deeply flawed book, nor in the literary 
essays that have followed in its wake, but in his work on the Palestine issue". See Ahmad, Orientalism and After, 160-161.

xxx Irfan Habib, "Critical Notes on Edward Said", International Socialism: A Quarterly Journal of Socialist Theory,

17 October, 2005: 130.

xxxi Habib 134.

xxxii Habib 134.

xxxiii Habib 135 .

xxxiv Habib 130.

xxxv See Mary Louise Pratt, Imperial Eyes: "One of my favorites in the monarch-of- all-I-survey genre comes from Richard Burton's Lake Regions of Central Africa, which appeared in 1860 and achieved considerable renown in that prolific and highly competitive era of travel writing. Here in a descriptive tour de force Burton renders the dramatic moment of his discovery of Lake Tanganyika" (201). Pratt reasonably points out that "the 'discovery' of sites like Lake Tanganyika involved making one's way to the region and asking the local inhabitants if they knew of any big lakes, etc. in the area, then hiring them to take you there, whereupon, with their guidance and support, you proceeded to discover what they already knew" (201). However, why single out Burton for particular censure or ridicule? Burton was able to discover things for himself much more successfully than other explorers of the period such as Stanley and Speke, due to his mastery of local languages and interest in history, geography, ethnography and anthropology.

xxxvi David Spurr, The Rhetoric of Empire: Colonial Discourse in Journalism, Travel Writing, and Imperial Administration (PostContemporary Interventions) (Durham, NC: Duke University Press, 1993) 18. "Pratt in her analysis of a passage in Burton's The Lake Regions of Central Africa (1860) identifies three parts of this rhetorical convention: the landscape is first aestheticized, then it is invested with a density of meaning intended to convey its material and symbolic richness, and finally it is described so as to subordinate it to the power of the speaker" (18).

xxxvii Orientalism 196.

xxxviii Dane Kennedy, The Highly Civilized Man (Cambridge, MA: Harvard University Press, 2005) 4.

xxxix Kennedy 83-84.

${ }^{\mathrm{xl}}$ Kennedy 9.

${ }^{x l i}$ Charles Darwin, The Origin of Species (London: John Murray, 1859). Darwin delayed publishing his conclusions for many years due to his fears concerning how they would be received. See Janet Brown, Darwin's Origin of Species: A Biography (Books That Changed the World) (London: Atlantic Monthly Press, 2007) 50.

xlii Frank Baker (Richard Burton), Stone Talk: Marvellous Sayings of a Petral Portion of Fleet Street, London, (London: Robert Hardwicke, 1865), "By freak of matter Adam burst/Through Simian womb!" (20).

xliii Edward Burnett Tylor, Primitive Culture: Researches into the Development of Mythology, Philosophy, Religion, Art and Custom (London: John Murray, 1871). Of particular importance was Tylor's insistence that the human brain was essentially the same in all races.

xliv Tyler vol. 2, 9 .

xlv Tyler, Preface to the Second edition.

xlvi Isabel Burton, The Life of Richard Burton (London: Chapman and Hall, 1893).

xlvii Isabel Burton. Vol. II 447

xlviii Isabel Burton. Vol. II 447-448.

xlix “The Life of Captain Sir Richard F. Burton. By His Wife.” The Edinburgh Review July-Oct 1893: 439.

${ }^{1}$ Fawn M. Brodie, The Devil Drives (New York: Norton,1984) 330.

${ }^{\text {li Kennedy } 259 .}$

lii See bibliography for an extensive list of Burton biographies.

liii Thomas Wright, The Life of Richard Burton (London: Everett \& Co., 1906) xii. "When I compared the two translations, page by page, I could scarcely believe my own eyes; and only one conclusion was possible. Burton, indeed, has taken from Payne at least three-quarters of the entire work. He has transferred many hundreds of sentences and clauses bodily. Sometimes, we come upon a whole page with only a word or two altered. In short, amazing to say, the public have given Burton credit for a gift which he did not possess--that of being a great translator." Robert Irwin has cast doubt on Wright's assertion concerning Burton's reliance on the Payne translation, explaining likenesses by the similar literary tastes shared by the two men. See Robert Irwin, The Arabian Nights: A Companion (London: Tauris Parke Paperbacks, 2004) 18.

liv Kennedy 261-263.

lv Kennedy 263-264.

lvi Kennedy 266-267.

lvii For example, see the Obscene Publications Act, 1959. This attempted to create a balance between the protection of real literature and the prosecution of pornography. Clause 4 argues: “...a person shall not be convicted of an offence against section 
two of this Act, and an order for forfeiture shall not be made under the foregoing section, if it is proved that publication of the article in question is justified as being for the public good on the ground that it is in the interests of science, literature, art or learning, or of other objects of general concern." See the "Obscene Publications Act 1959 (c.66)”, Ministry of Justice, HMSO.

lviii In 2008, a new biography of Burton was published by Jon R. Godsall. This work comes highly recommended by Mary S. Lovell.

lix Mary S. Lovell, A Rage to Live: A Biography of Richard and Isabel Burton (New York: Norton, 1998).

${ }^{1 x}$ Kennedy 278.

lxi Kennedy 131-163.

lxii Orientalism has given rise to a multitude of books both supportive and critical (and even has strongly influenced the creation of a literary theory: post-colonialism). One of the latest attacks on Said's theories has come from a Muslim source, albeit an apostate one. Ibn Warraq's wide-ranging critique is weakened by his clear preference for the West over the East and his apparent hatred for Islam. See Ibn Warraq, Defending the West: A Critique of Edward Said's Orientalism (London: Prometheus Books, 2007).

lxiii Bhabha's prose is often notoriously difficult to penetrate. In his most influential book, The Location of Culture, he seems to suggest that the West discourses about colonial peoples in binary terms and that the dominance of the first term in each binary opposition establishes the superior way in which the West regards other cultures. Examples of these binary oppositions would be: centre/margin, civilized/ savage, enlightened/ignorant. According to Bhabha, it is only through the linguistic disruption of these binary oppositions that a new and more egalitarian discourse between the West and its ex-colonies can take place by means of "hybridity" and "linguistic multi-vocality." The most practical way for this "disruption" to happen is through the culturally subversive writings of erstwhile colonial peoples. Bhabha ends his argument in the following way: "The problem of progress is not simply an unveiling of human perfectibility, not simply the hermeneutic of progress. In the performance of human doing, through the veil, emerges a figure of cultural time where perfectibility is not ineluctably tied to the myth of progressivism." See Homi K. Bhabha, The Location of Culture (New York: Routledge, 1994) 367. As well as his clear debt to Said in his view of colonialism as a "discourse", it should also be clear that Bhabha's ideas have been fundamentally shaped by French intellectuals such as Foucault, Lacan and, perhaps most importantly, the deconstructionism of Jacques Derrida who, in his most influential book, Of Grammatology, spoke of the ways in which a text might be deconstructed through a thorough understanding of its binary oppositions. See Jacques Derrida (translated by Gayatri Chakravorty Spivak), Of Grammatology (Baltimore: The John Hopkins University Press, 1998).

1xiv Orientalism 195-196.

lxv Orientalism 195-196.

${ }^{\text {lxvi }}$ Of course, Darwinism (and its offshoots) is of particular importance in this regard. 